\title{
16
}

\section{The Scholarship of Civic Engagement: Defining, Documenting, and Evaluating Faculty Work}

\author{
Robert G. Bringle, Julie A. Hatcher \\ Indiana University-Purdue University Indianapolis \\ Patti H. Clayton \\ North Carolina State University
}

Civic engagement, which is presented as teaching, research, and service in and with the community, presents new challenges for evaluating faculty work as part of the reappointment, promotion, and tenure process. The nature of service-learning, professional service, and participatory action research are examined as faculty work that can be scholarly (i.e., well informed) and the basis of scholarship (i.e., contributing to a knowledge base). As such, examples of evidence for documenting the work and issues associated with evaluating dossiers are presented.

uch of faculty work occurs on campus: teaching in classrooms, service $\mathrm{I}_{\text {to }}$ the university and discipline or profession, and research. However, each of these can also occur off campus when instructors deliver courses at remote sites, faculty provide professional services to the community (c.g., serving on boards, contributing to a government task force, consulting), and researchers collect data in communities. Figure 16.1 illustrates how community involvement is related to the traditional areas of faculty work. Although not part of this diagram, the intersection of teaching, research, and service in the community can occur when a faculty member designs and implements 
courses that use participatory action research. Community involvement can occur in all sectors of society (e.g., nonprofit, government, business) and has no geographic boundaries.

\section{FIGURE 16.1}

\section{Community Engagement as Faculty Work}

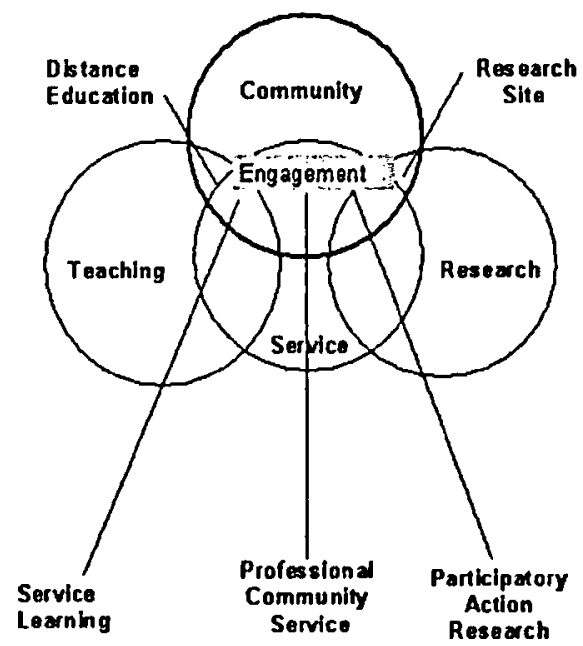

Engagement of Faculty Work in the Community

We differentiate between the terms community involvement and civic engagement in the following way: community involvement is defined primarily by location and includes faculty work that occurs in communities and in clinical settings either on or off campus. Civic engagement is a subset of community involvement and is defined by location as well as process (it occurs not only in but also with the community). According to this distinction, civic engagement develops partnerships that possess integrity and that emphasize participatory, collaborative, and democratic processes (e.g., design, implementation, assessment) that provide benefits to all constituencies and thus encompass service to the community. Civic engagement is consistent with many reinterpretations of community involvement that focus on the importance of reciprocity as a new model for these activities (e.g., Bringle, Games, \& Malloy, 1999a; Kellogg Commission, 1999). This distinction between community involvement and civic engagement is consistent with Boyer's (1990) call for fundamental changes in the structure and behavior of the academy. 
Furthermore, it is also consistent with Rice's (1996) observation that faculty work is moving from an emphasis on autonomous, individualistic work to collaborative, interdisciplinary work, and changing from the isolated character of higher education to a more public and democratic approach to academic work.

This chapter focuses on one set of implications from this shift in perspective to civic engagement: How should the scholarship of engagement be documented and reviewed as faculty work? Documenting and reviewing traditional research and classroom teaching are familiar territory for most academic institutions. In contrast, the nature of service-learning, professional service, and participatory action research (see Figure 16.1 shown earlier) are less familiar and may have unique qualities that warrant additional consideration as their scholarly nature is assessed. Each of these will be discussed as the basis for faculty work, scholarly work, and scholarship. We will begin with an overview of recent changes in the promotion and tenure process, followed by a discussion on defining and documenting service-learning, professional service, and participatory action research. In addition, issues related to evaluating dossiers, along with suggestions for faculty development and institutional change, will be offered.

\section{Emergence of Civic Engagement From Outreach and Community Involvement}

The manifestations of community involvement in higher education are remarkably varied. Faculty at many colleges and universities are involved in a range of community-based activities including cooperative extension, outreach, and continuing education programs; clinical and pre-professional programs; top-down administrative initiatives; centralized administrativeacademic units with outreach missions; faculty professional service; student volunteer initiatives; economic and political outreach; applied research; and most recently, service-learning courses (Thomas, 1999). Because each of these activities can be situated within the traditional areas of academic work (i.e., teaching, research, service) they do not necessarily produce any tension toward change in defining, documenting, and evaluating faculty work. However, new interpretations of and innovative approaches to community involvement, in particular service-learning courses, have presented opportunities for both altering the ways that faculty work is valued and reinvigorating the public mission of higher education. 
The emergence of civic engagement within higher education produces a dynamic tension on existing views of faculty work and can become a driver for a reexamination of traditional approaches for defining, documenting, and evaluating scholarship. The foundational work for considering new approaches to scholarship was put forth by Ernest Boyer (1990). He wrote extensively on the role of service, community, and values in education, and his later years focused on implications for faculty and higher education (Glassick, 1999). Boyer offered an expansion of the use of the term scholarship to encompass faculty work in four areas, including discovery, teaching, application, and integration (Boyer, 1990), and this was followed with an analysis of the attributes of scholarship that could apply to these more extensive types of faculty work (Glassick, Huber, \& Maeroff, 1997).

Boyer (1996) promoted a new model for higher education in which "the academy must become a more vigorous partner in searching for answers to our most pressing social, civic, economic, and moral problems, and it must affirm its historic commitment to society" (pp. 19-20). Boyer's vision did not simply target a quantitative increase in existing outreach and community programs, but rather called for fundamental changes in the academy. Boyer (1994) noted that "what is needed is not just more programs, but a larger purpose, a larger sense of mission, a larger clarity of direction" (p. A48). Boyer $(1994,1996)$ added to his new vision a call for the "scholarship of engagement," which "means connecting the rich resources of the university to our most pressing social, civic, and ethical problems, to our children, to our schools, to our teachers, and to our cities" (Boyer, 1996, p. 19). We assert that Boyer very intentionally articulated "scholarship" as an aspiration for his vision because of a belief that engagement could and should have the same scholarly qualities that are characteristic of traditional research.

Although Boyer's view of the scholarship of engagement can be interpreted as an expansion of application, the scholarship of engagement can also be viewed as a new approach that reinterprets the nature not only of application but also of discovery, integration, and teaching (Bringle, Games, \& Malloy, 1999b; Glassick, 1999; Rice, 2005). Many have built on Boyer's thinking and offered critical examinations that explore how community involvement can change the nature of faculty work, enhance student learning, better fulfill campus mission, influence strategic planning and assessment, and improve university-community relations (e.g., Boyer, 1994, 1996; Bringle et al., 1999a; Calleson, Jordan, \& Seifer, 2005; Colby, Ehrlich, Beaumont, \& Stephens, 2003; Edgerton, 1994; Harkavy \& Puckett, 1994; O'Meara \& Rice, 2005; Rice, 1996). 


\section{Promotion and Tenure as a Mechanism for Change}

Checkoway (2001) noted that asking faculty to do one set of activities when other activities are being rewarded is "dysfunctional for the individual and the institution" (p. 135). The control of the promotion and tenure process is unevenly distributed across various constituencies on campus (e.g., chairs and deans, faculty, committees, presidents, boards of trustees, unions), and perceptions differ on who has pivotal or significant control. Regardless of the specific distribution of control on a campus, there is an opportunity to use its leverage points as mechanisms for developing understanding for a broader view of scholarship that is prompted by civic engagement. In addition, this provides an opportunity for developing the institutional capacity to honor through the advancement process some civic engagement activities as scholarly academic work and as scholarship. Our discussion will focus attention on the review of tenure-track faculty for reappointment, promotion, and tenure (RPT). This is critically important to the future of civic engagement as a new way of thinking about academic work because, as Plater (2004) notes,

Regardless of the degree of prominence attached to civic engagement, in an era of diminishing resources and an increasing commitment to serve the public good, the aspirations for civic engagement and the support for faculty roles, rewards, and recognitions must be aligned with and proportionate to the institution's declared mission.

Thus, the RPT process can play a pivotal role in institutional transformation through the degree to which it reflects the evolving public mission on a campus.

Revising the RPT process can also improve the quality of both community involvement and civic engagement by driving change of other institutional processes that either support or deter faculty participation (e.g., hiring, annual review, faculty development, use of faculty time, institutional assessment, strategic planning). Plater (Plater, Chism, \& Bringle, 2005) suggests that critical examinations of RPT must consider the particular roles of criteria (e.g., what is valued?), standards (e.g., what constitutes different levels of performance within the criteria?), and evidence (c.g., what is presented to determine level of performance?). Optimally, criteria and standards will be clearly articulated and aligned, and evidence will then be brought forward by candidates so that well-informed decisions can be made by reviewers. Unfortunately, even when criteria are clear, there can be disparate views (e.g., across ranks, across disciplines, across individual reviewers) of standards and the 
quality of evidence of faculty work that is expected, particularly for the nontraditional types of academic work involved in civic engagement.

Change is occurring in higher education around issues related to faculty work and its appraisal as scholarship in RPT (O'Meara \& Rice, 2005). This change was aided when Glassick et al. (1997) delineated six qualities against which faculty work of all four types (i.e., discovery, teaching, integration, application) can be evaluated as scholarship. These six criteria include clear goals, adequate preparation, appropriate methods, significant results, effective communication and dissemination, and reflective critique. Similarly, Diamond and Adams (1993) identified six criteria for appraising scholarship, including discipline-related expertise, innovation, replicability, documentation, peer review, and significant impact. Both sets of criteria offer strong guidance for campuses to refine the RPT process.

Based on these analyses and the emergence of civic engagement, institutions of higher education have slowly begun to reexamine the structures, frameworks, and procedures for evaluating a broader range of faculty work as scholarly work (e.g., Bringle, Hatcher, Jones, \& Plater, 2006; Brukardt, Holland, Percy, \& Zimpher, 2004; Calleson, Jordan, et al., 2005; Committee on Institutional Cooperation, 2005; Driscoll \& Lynton, 1999; Gelmon \& Agre-Kippenhan, 2002; Michigan State University, 1996; O'Meara \& Rice, 2005; Sandmann, Foster-Fishman, Lloyd, Rauhe, \& Rosaen, 2000). In a recent study by O'Meara (2005), 2 out of 3 of the 729 chief academic officers surveyed reported that during the past 10 years, their institutions had changed mission and planning documents, amended faculty evaluation criteria, and provided incentive grants or developed flexible workload programs as a basis for a broader definition of scholarly work. Nevertheless, about only one-third of the chief academic officers observed increases in the scholarship of integration, student contact with faculty, and scholarship focused on civic engagement and professional service (O'Meara, 2005). The trajectory of these changes must continue, and administrative and faculty leaders must find ways to ensure that RPT reflects these changing views of scholarship.

Because higher education is still working to accommodate broader views of scholarship, especially those that result from civic engagement activities, the nature of service-learning, professional service, and participatory action research are examined as faculty work and the case is made that these activities can provide the basis for assessments that the work is scholarly (i.e., well informed) and scholarship (i.e., contributing to a knowledge base). 


\section{Civic Engagement: Service-Learning}

: Defining the Nature of the Pedagogy

Although not a new pedagogy (see Stanton, Giles, \& Cruz, 1999), servicelearning gained prominence during the 1990s due largely to the shift in focus of Campus Compact (www.compact.org) from cocurricular to curricular service, and developmental grants awarded by the Corporation for National and Community Service (www.nationalservice.org). Service-learning is defined as a

Course-based, credit-bearing educational experience in which students participate in an organized service activity that meets identified community needs, and reflect on the service activity in such a way as to gain further understanding of course content, a broader appreciation of the discipline, and an enhanced sense of civic responsibility. (Bringle \& Hatcher, 1995, p. 112)

Some campuses have adopted a broader definition that includes cocurricular or other activities, but in all cases service-learning must have an academic component that is connected to the service activities through structured reflection and must target both academic and civic learning outcomes.

Unlike many other forms of practice-based learning (e.g., cooperative education, extension service placements, field education, internships, practicum), service-learning is integrated into a course and has the intentional goal of developing civic skills and dispositions in students (Battistoni, 2002; Furco, 1996; Westheimer \& Kahne, 2003). Unlike cocurricular community service programs (e.g., volunteer programs, community outreach, student service organizations), service-learning is academic work in which the community service activities are used as a "text" that is interpreted, analyzed, and related to the content of a course in ways that permit a formal evaluation of the academic learning outcomes (Furco, 1996). Academic credit is based on the documented learning that occurs as a result of structured reflection on the community service, not just for the service itself. Reflection activities can take a variety of forms, including journals, written assignments, group discussion, multimedia presentations, and reports to the community agency (Eyler, Giles, \& Schmiede, 1996; Hatcher \& Bringle, 1997). Effective reflection activities should clearly link the service experience to the learning objectives; be structured; occur regularly; provide feedback from the instructor; and include the opportunity to explore, clarify, and alter values (Hatcher \& Bringle, 1997; Hatcher, Bringle, \& Muthiah, 2004). In addition, high-quality service-learning classes demonstrate reciprocity between 
the campus and the community, between academics and service providers, between students and community representatives, with each giving and receiving, each teaching and learning, and each gaining new understanding of and respect for the other.

Although there is more to civic engagement than service-learning, the values, theories, and practice of service-learning can serve as a basis for informing and valuing professional service and participatory action research (see Figure 16.1 shown earlier) as civic engagement. As such, service-learning becomes an impetus for higher education to examine critically both the methods and goals of a broad range of community involvement activities (e.g., Boyer, 1994, 1996; Bringle et al., 1999a; Clayton \& Ash, 2004; Colby et al., 2003; Harkavy \& Puckett, 1994; Langseth \& Plater, 2004; Rice, 1996; Zlotkowski, 2000).

\section{Documenting Service-learning as Teaching and Service}

There is emerging consensus from multiple disciplinary perspectives regarding the qualities of good learning environments (Chickering \& Gamson, 1987; Hatcher, 1997; Marchese, 1997; Pascarella \& Terenzini, 1991), and welldesigned service-learning courses will typically contain many of the components of effective learning environments for undergraduate students. Because service-learning heightens the role that students and communities can assume as constructors of knowledge, it reflects a paradigm shift in higher education from teaching to learning (Barr \& Tagg, 1995). Service-learning also broadens the perspective on learning outcomes beyond rote learning of discipline-specific content. Research shows that service-learning students are likely to have increased contact with faculty (Eyler \& Giles, 1999), interact and collaborate with others as they provide service (Eyler \& Giles, 1999), engage in active learning at their service activity and through reflection activities, devote more time to coursework (Sax \& Astin, 1997), participate in diverse ways of learning (Kolb, 1984), and develop more sophisticated ways of thinking about academic and civic matters (Ash, Clayton, \& Atkinson, 2005). Service-learning not only encompasses "serving to learn," but also "learning to serve." To the degree that educators are concerned with developing civic education (Battistoni, 2002; Westheimer \& Kahne, 2003), civic-minded professionals and graduates (Sullivan, 2005), and socially relevant knowledge (Altman, 1996), service-learning is a powerful pedagogy (Astin \& Sax, 1998; Eyler, Giles, Stenson, \& Gray, 2001; Sax \& Astin, 1997).

This discussion provides an outline of the various ways in which servicelearning instructors can demonstrate that what they are doing is not only good 
service-learning but also good teaching. Faculty who teach service-learning courses should be able to demonstrate in dossiers focused on teaching that, first and foremost, they designed learning opportunities that contain elements known to produce depth of understanding; that is, they are engaged in scholarly and well-informed teaching (Chickering \& Gamson, 1987; Marchese, 1997). All pedagogies should be held to this standard, not just service-learning. An even higher standard is for faculty to offer evidence not only that their pedagogy conforms to good practice but also that their instruction resulted in the desired learning outcomes. This standard of evidence should be expected in order to demonstrate scholarly teaching, whether through service-learning or some other pedagogy (Huber \& Hutchings, 2005). For example, Ash et al. (2005) found that structured, guided reflection in a service-learning course enhanced academic mastery, as well as the overall quality of thinking, when written products were independently assessed with a rubric. In addition, instructors of service-learning courses have the opportunity to demonstrate superior attainment of discipline-based educational objectives as well as civic outcomes (Ash et al., 2005; Eyler et al., 2001). This is the type of evidence that would be valued in a dossier to demonstrate excellence in teaching.

Instructors of service-learning courses can also demonstrate in their dossiers that their courses and students have had a positive impact on communities through service (e.g., through their students' community service). Often, through service-learning, faculty become professionally involved in a variety of ways at the community organization and this involvement can be documented as an important dimension of professional service. Additionally, service-learning instructors can provide evidence of having formed and maintained good working relationships with community partners that often have mutual benefits beyond the course (e.g., program development, grants). Again, this is not to say that service-learning courses should be held to a different standard than traditional instruction; rather, this set of outcomes illustrates the richness of evidence that can be presented by faculty documenting service-learning and demonstrates how service-learning raises the bar toward aspirations that should be held for documenting all types of teaching and learning.

When the faculty member's work and research on service-learning provides a basis for informing others about designing and implementing service-learning courses or increases understanding of teaching and learning in the discipline or campus-community partnerships, then it has the potential to be viewed as scholarship (i.e., scholarship of teaching and learning). As such, scholarship regarding service-learning contributes to scholarship on civic engagement. 


\section{Civic Engagement: Professional Service in and With the Community}

\section{Defining the Nature of Professional Service}

Professional service is the least well understood area of faculty work and typically results in a perfunctory approach toward institutional work (e.g., committees) and disciplinary and professional work (e.g., roles and responsibilities in associations). However, professional service can also be the basis for scholarly academic work and scholarship. Lynton (1995) provides a conceptual analysis of how professional service can aspire to scholarship, and Driscoll and Lynton (1999) provide further details and examples to illustrate how faculty can present documentation for professional service as scholarship.

Lynton (1995) limits the scope of professional service (versus private or personal service) to activities that are grounded in and informed by the faculty member's disciplinary or professional knowledge. Thus, for example, a faculty member in physics who is active in professional service in the community should only present for administrative review those activities that are related to physics or science (e.g., serving on a government task force on nuclear safety), not other activities (e.g., activities in the community that are unrelated, per se, to disciplinary expertise). The guidebook Service@ Indiana University (Center for Public Service and Leadership, 1999) presents a broader view of potential knowledge bases and suggests that professional service can draw on three types of knowledge: 1) as a member of a discipline or professional organization, 2) as an educator (i.e., the faculty member may have special expertise on pedagogy that transcends the discipline), and 3) as a member of an institution (i.e., institutional knowledge can enable a faculty member to accomplish tasks for which others are less able). Because most campuses have not had discussions about the nature of professional service, there is little guidance for faculty to know what should and should not be documented for RPT review beyond denotative lists.

Professional service as civic engagement reflects an approach to working with communities that emphasizes significant contributions through democratic and participatory processes. Faculty regard themselves as social trustces of knowledge and their expertise is valued as a public good intended for public purposes (Sullivan, 2005). When the professional service not only draws on the faculty member's knowledge base (i.c., scholarly professional service) but also contributes to knowledge bases (e.g., disciplines, profession practice, interdisciplinary) and other communities of practice, then it has the potential to be viewed as scholarship (i.c., scholarship of professional service). 


\section{- Documenting Professional Service as Civic Engagement}

Professional service is poorly documented for a number of reasons. Fundamentally, it is underappreciated as faculty work, it is poorly understood, and it is typically not seen as warranting academic evaluation. Inadequate documentation is often limited to listing only assignments and roles (e.g., membership on a committee), with no indication of the nature and results of the work (e.g., level of activity, significance of accomplishments), with no evidence of the role of the particular faculty member (e.g., chair, key author of a new policy), with little or no external peer review (although typically there will be peer review from colleagues and the chair), and with no reflective statement about how the service activities are consistent with the faculty member's professional goals and other interests (e.g., why these service activities?). This is analogous to documenting teaching by simply providing evidence that classes were held and, for research, by simply providing evidence that data were collected. Even when professional service is a secondary area of consideration in the review process, there should be annotation of some (but not necessarily all) service activities that is in proportion to their nature and significance. If there is no significance to the aggregate of service activities, then it should be acknowledged by reviewers as "unsatisfactory service" or unsatisfactorily documented service.

Academic advancement for professional service, whether in the community, university, or discipline/profession, should not be based solely on "doing good" nor doing one's administrative job well. Whereas such claims may be appropriate for some awards and for annual reviews, they should not be the basis for academic promotion in the RPT process. At the least, documentation of significant professional service activities should demonstrate that they are well informed by good practice (i.e., scholarly service).

When professional service becomes more salient in a faculty member's work, particularly for the civically engaged scholar, then the documentation should be correspondingly more complete and rigorous. This must occur when the professional service activities are claimed to be scholarly. Key questions that distinguish good service activities from activities that approach scholarly status include "What is the compelling intellectual question?" (Sandmann et al., 2000) and "How have others learned from your good work?" Scholarly claims will be warranted for professional service when documentation presents 1) multiple forms of evidence about the impact of the activities; 2) clear evidence of the academic qualities of the work, including innovation (versus repetitive, routinized activities); 3 ) effective communication to relevant stakeholders, including academic audiences (i.e., academic publications); 4) peer review of the work, including academic peers from the 
discipline; 5) evidence of professional growth in the work; and 6) contributions to a knowledge base (Center for Public Service and Leadership, 1999). When the professional service is not just community involvement but also aspires to being civic engagement, then there should also be evidence that it has been conducted in a manner that is reciprocal and mutually beneficial to the community partners, and that the results of the service activities have been shared in multiple ways with diverse stakeholders.

\section{Civic Engagement: Participatory Action Research}

\section{Defining the Nature of Participatory Action Research}

Whether applied or basic, documenting research is familiar territory. Participatory action research is civically engaged research that involves collaboration between the campus and community to identify mutually beneficial outcomes of the research (Strand, Cutforth, Stoecker, Marullo, \& Donohue, 2003). That is, the research is conducted in such a way that the academic participants benefit because it meets their scholarly interests (i.e., contributes to the academic knowledge base), and the community participants benefit because it meets their civic interests (e.g., informs action that promotes social justice and quality of life). To the degree that these motives and outcomes converge, the activities and the supporting partnership fulfill the expectations of civic engagement.

As a form of civic engagement, participatory action research is not just research in the community, but research with the community. As such, it democratizes knowledge and acknowledges different ways of knowing and different types of knowledge (Bender, 1997). In addition, those in the community are co-researchers who participate in the design, implementation, analysis, dissemination, and utilization of the research (Strand et al., 2003). Furthermore, to be scholarly (well informed), participatory action research requires not only that it produces meaningful results but also that the academic participant demonstrates how the work respects the context in which it takes place. When the research also contributes to the discipline or profession's knowledge base, improves the practices of participatory action research, or informs the academic community about how to undertake similar work, it then has the potential to be the basis of scholarship and part of the scholarship of engagement. 


\section{:Documenting Participatory Action Research as Research and Service}

In addition to traditional criteria for research (e.g., publications, peer review, grant funding, significance to the discipline), documenting participatory action research as scholarly, well-informed research and as scholarship, like documenting professional service in the community and service-learning, warrants some additional types of evidence. In all these cases, there is a broader collection of stakeholders (e.g., community partners) who can provide evidence beyond discipline-based or profession-based peers about the significance and impact of the research. The faculty member needs to demonstrate how the work has contributed to a body of knowledge not only for the discipline or profession (e.g., peer-reviewed publications) but also for the community (e.g., through effective communications that were appropriate for different audiences). Furthermore, documenting the nature of the partnerships that supported the work is integral.

\section{Supporting Faculty Participation in Civic Engagement}

Bringle et al. (2006) use Kolb's (1984) model as a framework for designing faculty development activities and campus interventions to support civic engagement: Concrete experiences provide a basis for observations and reflections, which lead to abstract conceptualizations that have new implications for action. Faculty are predisposed to abstract conceptualization and therefore can be receptive to workshops, lectures and conferences that discuss new models of teaching (e.g., service-learning) and research (e.g., participatory action research), and presentations by experts, all of which are aimed at broadening their views of scholarship. Similar interventions can target the gatekeepers for administrative review (e.g., chief academic officers, deans, chairs) and those who participate on RPT review committees.

Faculty are too often deterred from actively experimenting with civic engagement because of logistics (e.g., too little time, too much work) (see Abes, Jackson, \& Jones, 2002), so institutions need to find resources that can be devoted to support faculty (e.g., student scholarships for assistance with engagement, seminars, release time) and opportunities through which faculty and departments can enhance engagement activities (e.g., course development grants, engaged department grants). Because many faculty also lack knowledge and experience with civic engagement (Abes et al., 2002), they can benefit from concrete experiences (e.g., immersions in service-learning activities, neighborhood tours, visits to community agencies) that demonstrate the potential for community involvement to enhance their teaching, research, 
and service. Abes et al. (2002) found that faculty also appreciate learning from colleagues in their discipline/profession or on their campus about how they have developed scholarship around civic engagement (e.g., through presentations of exemplary engagement on web sites and in newsletters, through on-campus poster displays, sponsoring trips to disciplinary conferences). These venues provide opportunities for faculty active in civic engagement to be reflective about their work (e.g., through writing articles, participating on panels). Clayton and Ash (2005) have articulated the value of reflection by faculty as part of an immersion service-learning activity to help faculty better understand the nature of service-learning and to bring the lens of reflective practice and scholarship to bear on their work: Just as critical reflection helps students generate, deepen, and document their learning and growth, it can also provide these same outcomes for faculty. Those focused on faculty development can play a key role in reaching these outcomes by structuring faculty development and other interventions accordingly.

\section{Supporting Faculty in Documenting Civic Engagement}

Once faculty have gained an understanding of civic engagement and have the confidence to embark on this type of work, attention should be given to documentation. Faculty can be coached on how best to present their good work in ways that respond to campus guidelines and to gencral criteria for scholarship (Calleson, Kauper-Brown, \& Seifer, 2005). Workshops, one-on-one coaching, mock RPT reviews, and archiving successful dossiers can help faculty prepare dossiers that present the appropriate cvidence in a persuasive manner. Understanding the various guidelines and models early in a faculty member's career can provide strategies for accumulating pertinent evidence (Committee on Institutional Cooperation, 2005; Driscoll \& Lynton, 1999; Michigan State University, 1996), which can also be used for portfolios for awards, grant applications, and recognitions (Plater, 2004). An excellent dossier is one that educates readers from diverse backgrounds about the scholarly aspects of the work as sound academic work and creates advocates for the case.

Faculty development programs can also be designed to foster scholarship associated with service-learning and other aspects of civic engagement. Successful faculty learning communities support a group of faculty over the course of a year to explore a variety of topics and conduct scholarly work (c.g., Bringle, Games, Foos, Osgood, \& Osborne, 2000; Rice \& Stacey, 1997). A Boyer Scholars Faculty Development Program at Indiana University-Purdue 
University Indianapolis involves six faculty in scholarship and research in their service-learning course. The Service-Learning Program at North Carolina State University seeks out and creates opportunities for experienced service-learning faculty to coauthor articles, present on conference panels, and conduct research in collaboration with program staff. These initiatives intentionally build a cohort of faculty with the explicit goal of advancing their scholarship associated with civic engagement.

\section{Supporting Faculty in Evaluating Civic Engagement}

As Rice $(1996,2005)$ notes, the trajectory of change for an expanded view of scholarship, including engaged scholarship, faces obstacles that are deeply ingrained. Cherwitz (2005) suggests that key obstacles include "inflexible administrative structures, historically embedded practices, status quo thinking, and inertia" (p. 49). Because the work is often interdisciplinary, team oriented, process oriented, and diffuse in impact across nontraditional constituencies (e.g., beyond the discipline), the academy is not well prepared to review its documentation, which impedes cultural change. Examining the three nontraditional areas of faculty work that form the core of civic engagement (i.e., service-learning, professional service in the community, participatory action research) highlights the similarities that they have with implicit and explicit views of what constitutes scholarship. However, inertia as well as active resistance inhibit expanding views of scholarship beyond the traditional but narrow prescriptive presumption that if it not basic research published in one of the top-tier journals in the discipline, then it does not count. Changing RPT guidelines (Langseth \& Plater, 2004), while important for the opportunity of discussing issues and for providing structural support for change, are incomplete and insufficient. Braxton, Luckey, and Helland (2002) conducted a national survey of faculty in four disciplines from five different types of institutions to determine the extent to which Boyer's (1990) four types of scholarly work had achieved structural, procedural, and incorporation institutionalization-stages of institutionalization with incorporation being the highest level. All four types of scholarship achieved structural institutionalization, but only teaching and discovery were perceived as receiving significant consideration in the workload of faculty (procedural), and only discovery was firmly engrained in the values of the institutions surveyed and in the support offered to faculty (incorporation). This suggests that the changes are slow and that more focused institutional work must be devoted 
to changing not just RPT guidelines but also the culture of a campus in order for scholars to be rewarded for dedicating themselves to civic engagement.

Thus, in addition to changing RPT guidelines, it is important to consider other interventions that can support change in the institutional culture regarding what is recognized as scholarship. Diamond and Adams (1993) identify the importance of exccutive leadership, faculty as advocates, policies, and broad faculty ownership as key components in producing institutional change. Executive leadership is important, and chief academic officers must provide leadership to promote change (Langseth \& Plater, 2004; O'Meara, 2005). In addition, campuses are initiating change in other ways to support engaged scholarship (see campus case studies in Langseth \& Plater, 2004, and O'Meara \& Rice, 2005). Reexamination of mission statements and accreditation presents opportunities for campus deliberation.

Broadening discussion and exposure beyond current practitioners of civic engagement increases familiarity with and appreciation of the work among those least familiar with it (even if they do not do it), and helps prepare other faculty to understand how it can warrant claims of scholarly work and scholarship so that they can more effectively review dossiers. In addition, workshops and discussions can be directed at RPT committees (e.g., department, school, university), deans, and chairs about guidelines, changes in guidelines, and advising faculty about the guidelines. These can be complemented with presentations at new faculty orientation and in workshops for those preparing dossiers in ways that produce greater alignment among criteria, standards, and evidence.

The fundamental question that must be addressed across all campus interventions directed at structural and cultural change to the RPT process is "In what significant ways is the intellectual culture of your institution compatible and incompatible with programs that embrace civic engagement?" (Walshok, 2004). Answering that question candidly will provide guidance about designing campus-specific interventions to enhance the capacity to review dossiers and to support faculty work.

\section{Summary}

Cherwitz (2005) calls for academic engagement to result in a substantial shift in how we understand our purpose and how we conduct our work toward public purposes, public problem solving, and public participation in knowledge generation. Cherwitz suggests-as have many others in the past decade-that these changes will require radical rethinking of service, cpiste- 
mology, and the organizational processes and structures used to effect change. The risk is that the traditions of higher education will be more successful in changing work done under the banner of civic engagement than civic engagement is in changing the work of the academy.

In spite of the widespread lack of institutionalization (Braxton et al., 2002; O'Meara, 2005), faculty are venturing into civic engagement in increasing numbers (Campus Compact, 2005). However, as Glassick et al. (1997) challenged higher education to adapt to a new, broader vision of faculty work and of scholarship, they concluded by noting that "courage" may be a requisite without sufficient institutional support.

Scholars must gain confidence that through their courage to move beyond the ordinary they can enrich and further theoretical knowledge, strengthen practical applications of knowledge, and demonstrate new ways of looking at the connecting pints where different kinds of knowledge converge. (p. 66)

As laudable and important as courage may be, faculty should not be asked to undertake this work with only limited hope of recognition. Rather, as the result of deliberate campus work and commitments, faculty can be encouraged and supported in pursuing the scholarship of engagement, knowing that their good work will be honored as scholarly work. However, in absence of institutional work focused on criteria, standards, and evidence for civic engagement, the risk exists that is illustrated in a line from the movie Amadeus: "You are passionate, but you do not persuade" (Forsman, 1984).

Any discussion of RPT as it relates to faculty development activities designed to prepare faculty for engaged scholarship, its documentation, and its review, is necessarily embedded in a broader agenda (Bringle et al., 1999a; Gelmon \& Agre-Kippenhan, 2002; Sandmann et al., 2000; Calleson, KauperBrown, et al., 2005). For most campuses, positioning civic engagement within this broader context is complicated by 1) the civic agenda being poorly defined, 2) service, and how it might be integrated with teaching and research, is too often not a high priority, 3 ) there is a lack of leadership for these initiatives, and 4) the civic agenda is perceived as too laden with values, which are often considered messy and too subjective to be a component of rigorous scholarship (Wellman, 1999). Thus, Walshok (1999) has proposed that each campus seriously consider the following questions:

- Are you asking faculty to account for the public meaning and impact of their scholarship beyond the discipline or profession?

- How is civic engagement presented as an intellectual imperative? 
- How is the institution intentionally supporting faculty (e.g., enabling infrastructures) with an interest in civic engagement activities?

Broad campus discussions answering these questions coupled with dedicated executive leadership can contribute to producing a culture that supports, recognizes, and rewards a more inclusive view of scholarly work that will include civic engagement.

\section{References}

Abes, E. S., Jackson, G., \& Jones, S. R. (2002, Fall). Factors that motivate and deter faculty use of service-learning. Michigan Journal of Community Service Learning, 9(1), 5-17.

Altman, I. (1996, April). Higher education and psychology in the millennium. American Psychologist, 51(4), 371-378.

Ash, S. L., Clayton, P. H., \& Atkinson, M. P. (2005, Spring). Integrating reflection and assessment to capture and improve student learning. Michigan Journal of Community Service Learning, 11(2), 49-60.

Astin, A. W., \& Sax, L. J. (1998, May/June). How undergraduates are affected by service participation. Journal of College Student Development, 39(3), 251-263.

Barr, R. B., \& Tagg, J. (1995, November/December). From teaching to learning-A new paradigm for undergraduate education. Change, 27(6), 12-25.

Battistoni, R. (2002). Civic engagement across the curriculum: A resource book for service-learning faculty in all disciplines. Providence, RI: Campus Compact.

Bender, T. (1997). Intellect and public life: Essays on the social history of academic intellectuals in the United States. Baltimore, MD: Johns Hopkins University Press.

Boyer, E. L. (1990). Scholarship reconsidered: Priorities of the professoriate. Princeton, NJ: Carnegic Foundation for the Advancement of Teaching.

Boyer, E. L. (1994, March 9). Creating the new American college. The Chronicle of Higher Education, p. A48.

Boyer, E. L. (1996, Spring). The scholarship of engagement. Journal of Public Service and Outreach, $1(1), 11-20$.

Braxton, J. W., Luckey, W., \& Helland, P. (2002). Institutionalizing a broader view of scholarship through Boyer's four domains (ASHE-ERIC Higher Education Report, 29[2]). San Francisco, CA: Josscy-Bass. 
Bringle, R. G., Games, R., Foos, C. L., Osgood, R., \& Osborne, R. (2000, February). Faculty Fellows Program: Enhancing integrated professional development through community service. American Behavioral Scientist, 43(5), 882-894.

Bringle, R. G., Games, R., \& Malloy, E. A. (Eds.). (1999a). Colleges and universitics as citizens. Needham Heights, MA: Allyn \& Bacon.

Bringle, R. G., Games, R., \& Malloy, E. A. (1999b). Colleges and universities as citizens: Reflections. In R. G. Bringle, R. Games, \& E. A. Malloy (Eds.), Colleges and universities as citizens (pp. 193-204). Needham Heights, MA: Allyn \& Bacon.

Bringle, R. G., \& Hatcher, J. A. (1995, Fall). A service-learning curriculum for faculty. Michigan Journal of Community Service Learning, 2(1), 112-122.

Bringle, R. G., Hatcher, J. A., Jones, S., \& Plater, W. M. (2006). Sustaining civic engagement: Faculty development, roles, and rewards. Metropolitan Universities Journal, $17(1), 62-74$.

Brukardt, M. J., Holland, B., Percy, S. L., \& Zimpher, N. (2004). Calling the question: Is higher education ready to commit to community engagement? A Wingspread statement. Milwaukee, WI: University of Wisconsin-Milwaukee, Milwaukee Idea Office.

Calleson, D. C., Jordan, C., \& Seifer, S. D. (2005, April). Community-engaged scholarship: Is faculty work in communities a true academic enterprise? Academic Medicine, $80(4), 317-321$.

Calleson, D. C., Kauper-Brown, J., \& Seifer, S. D. (2005). Community-engaged scholarship toolkit. Seattle, WA: Community-Campus Partnerships for Health.

Campus Compact. (2005). Season of service. Providence, RI: Campus Compact.

Center for Public Service and Leadership, Indiana University. (1999). Service@ Indiana University: Defining, documenting, and evaluating. Indianapolis, IN: Author.

Checkoway, B. (2001, March). Renewing the civic mission of the American research university. Journal of Higher Education, 72(2), 125-147.

Cherwitz, R. A. (2005, November/December). A new social compact demands real change: Connecting the university to the community. Change, 37(6), 48-49.

Chickering, A. W., \& Gamson, Z. F. (1987, June). Seven principles for good practice in undergraduate education. AAHE Bulletin, 39(7), 3-7.

Clayton, P. H., \& Ash, S. L. (2004, Fall). Shifts in perspective: Capitalizing on the counter-normative nature of service-learning. Michigan Journal of Community Service Learning, $11(1), 59-70$. 
Clayton, P. H., \& Ash, S. L. (2005, September). Reflection as a key component in faculty development. On the Horizon, 13(3), 161-169.

Colby, A., Ehrlich, T., Beaumont, E., \& Stephens, J. (2003). Educating citizens: Preparing America's undergraduates for lives of moral and civic responsibility. San Francisco, CA: Jossey-Bass.

Committee on Institutional Cooperation. (2005). Resource guide and recommendations for defining and benchmarking engagement. Champaign, IL: Author.

Diamond, R. M., \& Adams, B. (Eds.). (1993). New directions for higher education: No. 81. Recognizing faculty work: Reward systems for the year 2000. San Francisco, CA: Jossey-Bass.

Driscoll, A., \& Lynton, E. A. (1999). Making outreach visible: A guide to documenting professional service and outreach. Washington, DC: American Association for Higher Education.

Edgerton, R. (1994). The engaged campus: Organizing to serve society's needs. AAHE Bulletin, 47(1), 2-4.

Eyler, J., \& Giles, D. E., Jr. (1999). Where's the learning in service-learning? San Francisco, CA: Jossey-Bass.

Eyler, J., Giles, D. E., Jr., \& Schmiede, A. (1996). A practitioner's guide to reflection in service-learning: Student voices and reflections. Nashville, TN: Vanderbilt University.

Eyler, J., Giles, D. E., Jr., Stenson, C. M., \& Gray, C. J. (2001). At a glance: What we know about the effects of service-learning on college students, faculty, institutions, and communities, 1993-2000 (3rd ed.). Nashville, TN: Vanderbilt University.

Forsman, A. (Director). (1984). Amadeus [Motion picture]. United States: Warner Brothers.

Furco, A. (1996). Service-learning: A balanced approach to experiential education. In B. Taylor (Ed.), Expanding boundaries: Serving and learning (pp. 2-6). Washington, DC: Corporation for National Service.

Gelmon, S. G., \& Agre-Kippenhaan, S. (2002, January). Promotion, tenure, and the engaged scholar: Keeping the scholarship of engagement in the review process. AAHE Bulletin, 54(5), 7-11.

Glassick, C. E. (1999). Ernest L. Boyer: Colleges and universities as citizens. In R. G. Bringle, R. Games, \& E. A. Malloy (Eds.), Universities and colleges as citizens (pp. 17-30). Needham Heights, MA: Allyn \& Bacon.

Glassick, C. E., Huber, M. T., \& Maeroff, G. I. (1997). Scholarship assessed: Evaluation of the professoriatc. San Francisco, CA: Josscy-Bass. 
Harkavy, I., \& Puckett, J. L. (1994, September). Lessons from Hull House for the contemporary urban university. Social Science Review, 68(3), 299-321.

Hatcher, J. A. (1997, June). Classroom assessment techniques: Ways to improve teaching and learning in a service learning class. Paper presented at the American Association for Higher Education Assessment Forum, Miami, FL.

Hatcher, J. A., \& Bringle, R. G. (1997, Fall). Reflections: Bridging the gap between service and learning. Journal of College Teaching, 45(4), 153-158.

Hatcher, J. A., Bringle, R. G., \& Muthiah, R. (2004, Fall). Designing effective reflection: What matters to service learning? Michigan Journal of Community Service Learning, $11(1), 38-46$.

Huber, M. T., \& Hutchings, P. (2005). The advancement of learning: Building the teaching commons. San Francisco, CA: Jossey-Bass.

Kellogg Commission on the Future of State and Land-Grant Universities. (1999). Returning to our roots: The engaged institution. Washington, DC: National Association of State Universities and Land-Grant Colleges.

Kolb, D. A. (1984). Experiential learning: Experience as the source of learning and development. Upper Saddle River, NJ: Prentice-Hall.

Langseth, M., \& Plater, W. M. (Eds.). (2004). Public work and the academy: An academic administrator's guide to civic engagement and service-learning. Bolton, MA: Anker.

Lynton, E. A. (1995). Making the case for professional service. Washington, DC: American Association for Higher Education.

Marchese, T. J. (1997). The new conversations about learning: Insights from neuroscience and anthropology, cognitive studies, and work-place studies. In Assessing impact: Evidence and action (pp. 79-95). Washington, DC: American Association for Higher Education.

Michigan State University. (1996). Points of distinction: A guidebook for planning and evaluating quality outreach (Rev. ed.). East Lansing, MI: Michigan State University.

O'Meara, K. (2005). Effects of encouraging multiple forms of scholarship nationwide and across institutional types. In K. O'Meara \& R. E. Rice, Faculty priorities reconsidered: Rewarding multiple forms of scholarship (pp. 255-289). San Francisco, CA: Jossey-Bass.

O'Meara, K., \& Rice, R. E. (2005). Faculty priorities reconsidered: Rewarding multiple forms of scholarship. San Francisco, CA: Jossey-Bass.

Pascarella, E. T., \& Terenzini, P. T. (1991). How college affects students: Findings and insights from twenty yours of research. San Francisco, CA: Jossey-Bass. 
Plater, W. M. (2004, June). What recognitions and rewards should a campus crcate to promote civic engagement of students? Paper presented at the Wingspread Conference, Racine, WI.

Plater, W. M., Chism, N. V. N., \& Bringle, R. G. (2005, February). Revising promotion and tenure guidelines. Panel presented at the meeting of the American Association of State Colleges and Universities, San Diego, CA.

Rice, D., \& Stacey, K. (1997). Small group dynamics as a catalyst for change: A faculty development model for academic service-learning. Michigan Journal of Community Service Learning, 4, 64-71.

Rice, R. E. (1996). Making a place for the new American scholar (New Pathways Working Paper Series No. 1). Washington, DC: American Association for Higher Education.

Rice, R. E. (2005). "Scholarship Reconsidered": History and context. In K. O'Meara \& R. E. Rice, Faculty priorities reconsidered: Rewarding multiple forms of scholarship (pp. 17-31). San Francisco, CA: Jossey-Bass.

Sandmann, L. R., Foster-Fishman, P. G., Lloyd, J., Rauhe, W., \& Rosaen, C. (2000, January/February). Managing critical tensions: How to strengthen the scholarship component of outreach. Change, 32(1), 44-52.

Sax, L. J., \& Astin, A. W. (1997, Summer/Fall). The benefits of service: Evidence from undergraduates. Educational Record, 78(3-4), 25-32.

Stanton, T. K., Giles, D. E., Jr., \& Cruz, N. I. (1999). Service-learning: A movement's pioneers reflect on its origins, practice, and future. San Francisco, CA: Jossey-Bass.

Strand, K., Marullo, S., Cutforth, N., Stoecker, R., \& Donohue, P. (2003). Communitybased research and higher education: Principles and practices. San Francisco, CA: Jossey-Bass.

Sullivan, W. M. (2005). Work and integrity: The crisis and promise of professionalism in America (2nd ed.). San Francisco, CA: Jossey-Bass.

Thomas, N. (1999). The institution as a citizen: How colleges and universitics enhance their civic roles (Working Paper No. 22). Boston, MA: University of Massachusetts Boston, New England Resource Center for Higher Education.

Walshok, M. L. (1999). Strategies for building the infrastructure that supports the engaged campus. In R. G. Bringle, R. Games, \& E. A. Malloy (Eds.), Colleges and universities as citizens (pp. 74-95). Needham Heights, MA: Allyn \& Bacon.

Walshok, M. L. (2004, March). It's not just about public service: The intellectual bencfits of civic engagement. Colloquium presented at Indiana University-Purdue University Indianapolis, Indianapolis, IN. 
Wellman, J. V. (1999). Contributing to the civic good: Assessing and accounting for the civic contributions of higher education. Washington, DC: Institute for Higher Education Policy.

Westheimer, J., \& Kahne, J. (2003, Winter). What kind of citizen? Political choices and educational goals. Campus Compact Reader, 3(3), 1-13.

Zlotkowski, E. (2000, Fall). Service-learning in the disciplines. Michigan Journal of Community Service Learning [Special issue], 61-67. 